Supporting Information

\title{
Rearrangements of a Water Molecule in Both Directions Between Two Hydrogen-Bonding Sites of 5-Hydroxyindole Cation: Experimental Determination of the Energy Threshold for the Rearrangement
}

Takamasa Ikeda, Kenji Sakota*, Hiroshi Sekiya

Department of Chemistry, Faculty of Science, and Department of Molecular Chemistry, Graduate School of Science, Kyushu University, 744 Motooka, Nishi-ku, Fukuoka 819-0395, Japan

E-mail: sakota@chem.kyushu-univ.jp

\section{Contents}

1. IRPD spectra of $\left[5 \mathrm{HI}-\left(\mathrm{H}_{2} \mathrm{O}\right)_{1}\right]^{+}$measured in the region of $2800-3800 \mathrm{~cm}^{-1}$ (Figure S1).

2. Calculated stable structure of $\left[5 \mathrm{HI}(\mathrm{CH})-\left(\mathrm{H}_{2} \mathrm{O}\right)_{1}\right]^{+}$and $\left[5 \mathrm{HI}(\pi)-\left(\mathrm{H}_{2} \mathrm{O}\right)_{1}\right]^{+}$in the $\mathrm{D}_{0}$ state (Figure S2).

3. PIE spectrum of $5 \mathrm{HI}(\mathrm{NH})-\left(\mathrm{H}_{2} \mathrm{O}\right)_{1}$ in the wide region (Figure $\mathrm{S} 3$ ). 
1. IRPD spectra of $\left[5 \mathrm{HI}-\left(\mathrm{H}_{2} \mathrm{O}\right)_{1}\right]^{+}$in the region of $2800-3800 \mathrm{~cm}^{-1}$ (Figure S1).

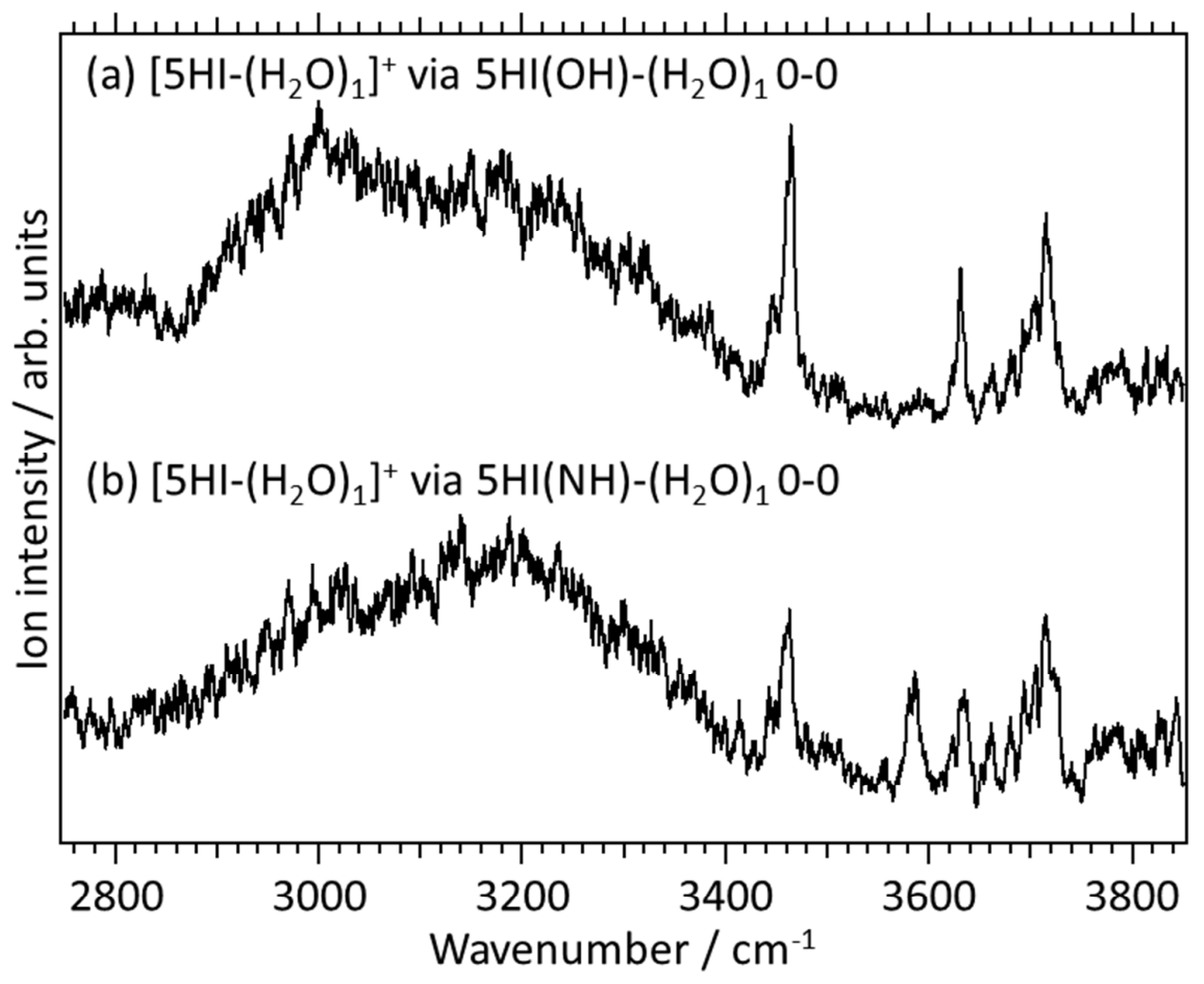

Figure S1. IRPD spectra of $\left[5 \mathrm{HI}-\left(\mathrm{H}_{2} \mathrm{O}\right)_{1}\right]^{+}$produced by R2PI via the origin of (a) $5 \mathrm{HI}(\mathrm{OH})-\left(\mathrm{H}_{2} \mathrm{O}\right)_{1}$ and (b) $5 \mathrm{HI}(\mathrm{NH})-\left(\mathrm{H}_{2} \mathrm{O}\right)_{1}$, in the region of $2800-3800 \mathrm{~cm}^{-1}$.

IRPD spectra of $\left[5 \mathrm{HI}-\left(\mathrm{H}_{2} \mathrm{O}\right)_{1}\right]^{+}$in the region of $2800-3800 \mathrm{~cm}^{-1}$ is shown in Figure S1. $\left[5 \mathrm{HI}-\left(\mathrm{H}_{2} \mathrm{O}\right)_{1}\right]^{+}$was produced by R2PI via the $\mathrm{S}_{1}-\mathrm{S}_{0}$ origin of (a) $5 \mathrm{HI}(\mathrm{OH})-\left(\mathrm{H}_{2} \mathrm{O}\right)_{1}$ and (b) $5 \mathrm{HI}(\mathrm{NH})-\left(\mathrm{H}_{2} \mathrm{O}\right)_{1}$. Broad features around $2800 \sim 3400 \mathrm{~cm}^{-1}$ are typically attributed to the H-bonded $v_{\mathrm{OH}}$ and $v_{\mathrm{NH}}$ transitions, which may slightly saturate because of their strong transition intensities. The broad feature around $3000 \mathrm{~cm}^{-1}$ in (a) may be assigned to the H-bonded $v_{\mathrm{OH}}$ band of $\left[5 \mathrm{HI}(\mathrm{OH})-\left(\mathrm{H}_{2} \mathrm{O}\right)_{1}\right]^{+}$while that around $3200 \mathrm{~cm}^{-1}$ in (b) may be assigned to the H-bonded $v_{\mathrm{NH}}$ band of $\left[5 \mathrm{HI}(\mathrm{NH})-\left(\mathrm{H}_{2} \mathrm{O}\right)_{1}\right]^{+}$. 


\section{Calculated stable structure of $\left[5 \mathrm{HI}(\mathrm{CH})-\left(\mathrm{H}_{2} \mathrm{O}\right)_{1}\right]^{+}$and $\left[5 \mathrm{HI}(\pi)-\left(\mathrm{H}_{2} \mathrm{O}\right)_{1}\right]^{+}$in} the $\mathrm{D}_{0}$ state (Figure $\mathrm{S} 2$ ).

(a) $\left[5 \mathrm{HI}(\mathrm{CH} 1)-\left(\mathrm{H}_{2} \mathrm{O}\right)_{1}\right]^{+}$

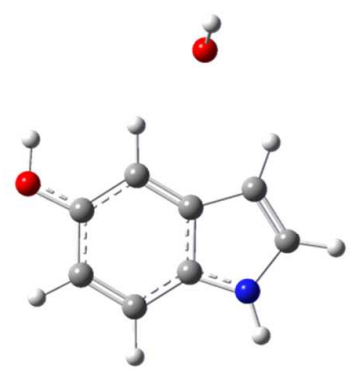

$\left(+3004 \mathrm{~cm}^{-1}\right)$ (b) $\left[5 \mathrm{HI}(\mathrm{CH} 2)-\left(\mathrm{H}_{2} \mathrm{O}\right)_{1}\right]^{+}$

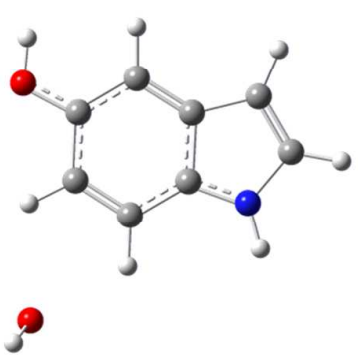

$\left(+3147 \mathrm{~cm}^{-1}\right)$

(c) $\left[5 \mathrm{HI}(\mathrm{CH} 3)-\left(\mathrm{H}_{2} \mathrm{O}\right)_{1}\right]^{+}$

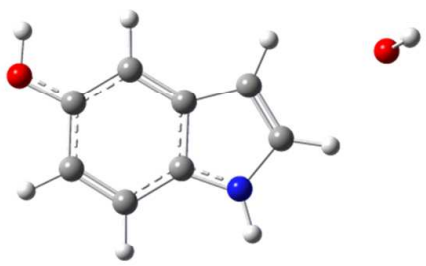

$$
\left(+3330 \mathrm{~cm}^{-1}\right)
$$

(d) $\left[5 \mathrm{HI}(\pi 1)-\left(\mathrm{H}_{2} \mathrm{O}\right)_{1}\right]^{+}$
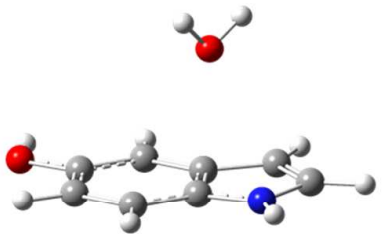

$\left(+3324 \mathrm{~cm}^{-1}\right)$ (e) $\left[5 \mathrm{HI}(\pi 2)-\left(\mathrm{H}_{2} \mathrm{O}\right)_{1}\right]^{+}$
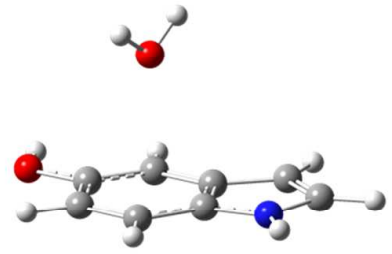

$\left(+3342 \mathrm{~cm}^{-1}\right)$

Figure S2. Calculated stable structures of $(\mathrm{a}-\mathrm{c})\left[5 \mathrm{HI}(\mathrm{CH})-\left(\mathrm{H}_{2} \mathrm{O}\right)_{1}\right]^{+}$and $(\mathrm{d}, \mathrm{e})$ $\left[5 \mathrm{HI}(\pi)-\left(\mathrm{H}_{2} \mathrm{O}\right)_{1}\right]^{+}$in the $\mathrm{D}_{0}$ state, respectively, obtained at the M06-2X/aug-cc-pVDZ level of theory. Relative stabilization energies from $\left[5 \mathrm{HI}(\mathrm{OH})-\left(\mathrm{H}_{2} \mathrm{O}\right)_{1}\right]^{+}$are given in wavenumber units. The zero-point vibrational energy and basis set superposition error are corrected in all values. 
3. PIE spectrum of $5 \mathrm{HI}(\mathrm{NH})-\left(\mathrm{H}_{2} \mathrm{O}\right)_{1}$ measured up to $\left(I E_{0}^{N H}+3300\right) \mathrm{cm}^{-1}$ (Figure S3).

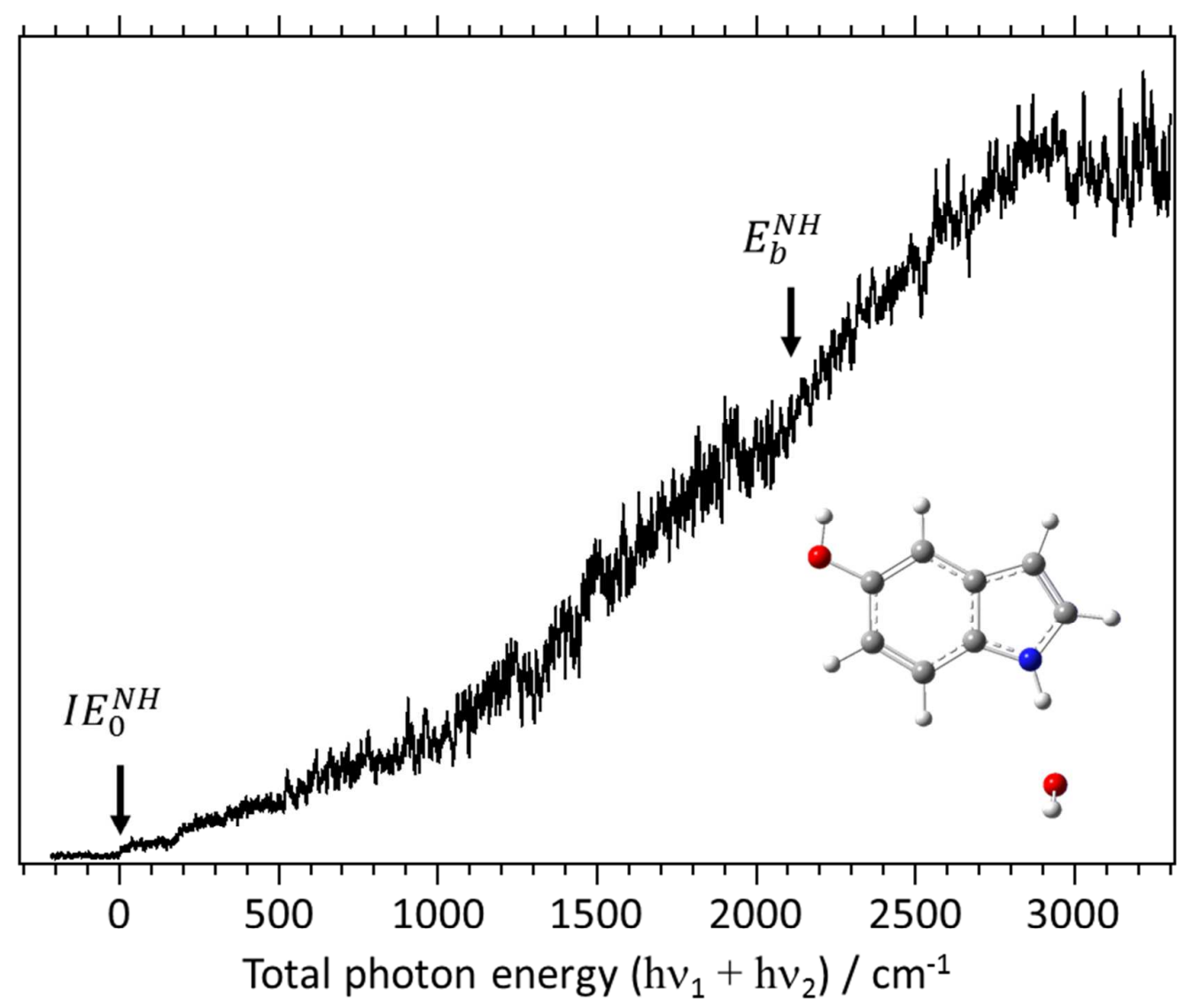

Figure S3. PIE spectrum of $5 \mathrm{HI}(\mathrm{NH})-\left(\mathrm{H}_{2} \mathrm{O}\right)_{1}$ measured up to $\left(I E_{0}^{N H}+3300\right) \mathrm{cm}^{-1}$.

Figure S3 displays PIE spectrum of $5 \mathrm{HI}(\mathrm{NH})-\left(\mathrm{H}_{2} \mathrm{O}\right)_{1}$ measured up to $\left(I E_{0}^{N H}+3300\right) \mathrm{cm}^{-1}$. The PIE curve of $5 \mathrm{HI}(\mathrm{NH})-\left(\mathrm{H}_{2} \mathrm{O}\right)_{1}$ plateaus above ca. $I E_{0}^{N H}+$ $3000 \mathrm{~cm}^{-1}$, suggesting that the total photon energy $\left(\mathrm{h} v_{1}+h v_{2}\right)$ exceeds the Franck-Condon region of $\left[5 \mathrm{HI}(\mathrm{NH})-\left(\mathrm{H}_{2} \mathrm{O}\right)_{1}\right]^{+}$around $I E_{0}^{N H}+3000 \mathrm{~cm}^{-1}$. 